\title{
ANALISIS STRUKTUR MODAL DAN IMPLIKASINYA TERHADAP STRATEGI PEMBIAYAAN (STUDI KASUS PT XYZ)
}

\author{
${ }^{1}$ Ramadhoni Tiar Saputra, Sekolah Bisnis Institut Pertanian Bogor \\ Email : ramadhoni.tiar@yahoo.com \\ ${ }^{2}$ Noer Azam Achsani : Sekolah Bisnis Institut Pertanian Bogoer \\ Email : achsani@yahoo.com \\ ${ }^{3}$ Hendro Sasongko, Universitas Pakuan \\ hendro.sasongko@unpak.ac.id
}

\begin{abstract}
PT XYZ is a state-owned subsidiary that is engaged in extending credit to micro, small, medium enterprises and cooperatives. From 2014 to 2017 the age of PT XYZ's debt has increased, this shows that the company is increasingly difficult to meet its payment obligations. This study tries to analyze the capital structure with traditional approaches and miller modligliani and working capital based on the cash conversion cycle. It is known that there are differences in optimal debt composition from simulation calculations with reality calculations but there are no problems with the company's working capital. The condition of the capital structure of PT XYZ is known to be better using the traditional approach because it is able to provide a smaller WACC value than using the modligliani miller approach.
\end{abstract}

Keywords: Capital Structure, Modligliani, Traditional Approach, Working Capital.

\section{PENDAHULUAN}

Tantangan UMKM tiap tahunnya semakin berat dan ketat. Dimana mereka harus mampu bersaing dengan produk luar negeri serta UMKM sejenisnya. Disisi lain banyak UMKM yang mengalami permasalahan permodalan yang menyebabkan tidak dapat naik tingkat atau mengembangkan usahanya lebih besar lagi. Hal ini terjadikarena banyak UMKM yang tidak dapat mengakses pada sumber permodalan. Padahal dalam UU No 3 Tahun 2004 terdapat kebijakan dari pemerintah yang memberikan perintah pada Bank Indonesia untuk membantu mengembangkan UMKM dan Koperasi melalui Kredit Likuiditas Bank Indonesia. Pada proses implementasinya Bank Indonesia memberikan wewenang pada beberapa perusahaan pemerintah untuk mengurusi kredit pada UMKM. Dimana produk kredit tersebut dibagi berdasarkan beberapa jenis seperti kredit usaha tani, kredit koperasi, kredit kepemilikan rumah sederhana dan sangat sederhana, dan skim kredit. Tercatat bahwa tiap tahunnya kredit yang disalurkan Pemerintah terus meningkat dapat dilihat seperti berikut :

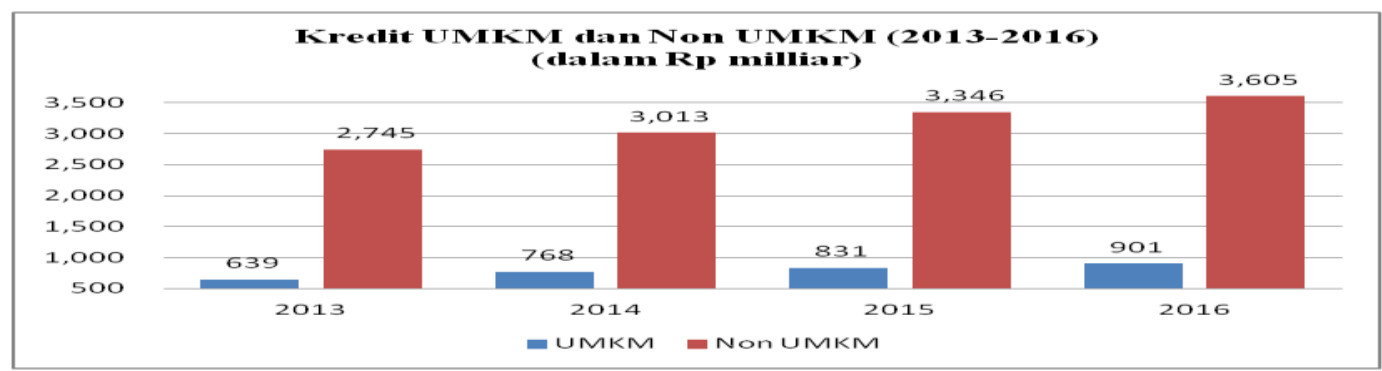

Gambar 1 Kredit UMKM dan Non UMKM (2013-2016) dalam Milliar Rupiah

Sumber : Bank Indonesia (2017)

Berdasarkan gambar 1 diatas diketahui bahwa kredit non UMKM jauh lebih unggul dari pada kredit UMKM. Namun kredit yang disalurkan kepada UMKM tiap tahunnya memiliki persentase pertumbuhan lebih tinggi dari pada kredit yang disalurkan kepada non UMKM. Tercatat pada tahun 2013 ke 2014 meningkat sebesar 17 persen, 2014 ke 2015 dan 2015 ke 2016 meningkat sebesar 8 persen atau rata-rata sebesar 11 persen tiap tahunnya dimana kredit non UMKM hanya dapat tumbuh sebesar 9 persen. 
Disadari terdapat beberapa faktor penting yang menyebabkan meningkatnya kredit UMKM adalah akibat dari dukungan melalui program pemerintah serta akses perbankan yang semakin mudah untuk di lakukan oleh para pemilih UMKM. Disisi lain adanya potensi besar yang didukung dari Peraturan Bank Indonesia No 17 Tahun 2015 menjelaskan bahwa setiap bank wajib minimal menyalurkan kredit kepada UMKM sebesar 20 persen.

PT XYZ merupakan salah satu anak perusahaan BUMN yang bergerak dibidang penyaluran kredit kepada usaha mikro kecil menengah dan koperasi. Core Business dari PT XYZ sendiri menyediakan bangunan, gedung serta sarana untuk holdingnya dan pihak lain, namun sampai saat ini penjualan PT XYZ masih didominasi oleh holding. Dapat dikatakan sampai 2017 bahwa operasional dan keuangan PT XYZ sangat tergantung pada holding. Sejalan dengan strategi holding, PT XYZ melakukan pengembangan usaha secara agresif, dimana terus memperbanyak gedung atau bangunan yang digunakan untuk kantor perwakilan di berbagai kota di Indonesia. Tercatat sejak tahun 2015 PT XYZ terus menambah jumlah kantornya seperti berikut :

Tabel 1 Penambahan Gedung PT XYZ 2015-2017

\begin{tabular}{ccccc}
\hline Tipe Gedung & $\mathbf{2 0 1 5}$ & $\mathbf{2 0 1 6}$ & $\mathbf{2 0 1 7}$ & $\begin{array}{c}\text { Total Penambahan } \\
\text { Gedung }\end{array}$ \\
\hline A & 6 & 9 & 4 & 19 \\
B & 5 & 39 & 47 & 91 \\
C & & 209 & 1007 & 1216 \\
\cline { 2 - 5 } Penambahan Gedung Pertahum & $\mathbf{1 1}$ & $\mathbf{2 5 7}$ & $\mathbf{1 0 5 8}$ & $\mathbf{1 3 2 6}$ \\
\hline
\end{tabular}

Sumber : PT XYZ (2017)

Dari tabel 1 diatas jelas bahwa sejak tahun 2015 sebanyak 11 gedung, 2016 sebanyak 257 gedung dan 2017 mencapai 1058 gedung. Hal ini menunjukan adanya aktifitas investasi yang besar yang perlu dibiayai dari berbagai sumber pembiayaan yang paling menguntungkan perusahaan. Dijelaskan pada penyusunan anggaran tiap tipe gedung memiliki nilai yang berbeda-beda yang dapat di estimasi sekitar Rp 400 juta pergedung barunya. PT XYZ dituntut untuk mampu memenuhi kebutuhan dana dalam rangka investing decision. Keputusan investasi tersebut dilakukan untuk meningkatkan value of firm (Brigham, 2000). Dalam mencapai tujuan tersebut perusahaan melakukan aktifitas financing decision melalui pencarian dana yang bersumber dari internal financing dengan menahan laba yang didapat perusahaan serta external financing yang didapat dari pinjaman dari berbagai pihak.

Pada dasarnya aktifitas bisnis yang dilakukan PT XYZsaat ini dengan melakukan banyak penambahan gedung, yang nantinya dapat disewakan baik kepada holding maupun perusahaan lainnya. Dalam prosesnya pendanaan aktifitas tersebut perusahaan dituntut untuk dapat efektif dan efisien sehingga tidak menganggu kebutuhan operasional serta aktifitas investasi lainnya.Sehingga manajer keuangan dituntut harus dapat mencari alternatif terbaik dalam aktifitas investasi yang dilakukan tersebut. Manajer keuangan dituntut untuk dapat mencari opsi sebagai alternative terbaik. Prosesnya investasi PT XYZ menggunakan kombinasi beberapa sumber pendanaan baik equity yang bersumber dari retained earning dan utang (jangka pendek dan panjang). Dapat dilihat pada tabel 2 kondisi perkembangan pasiva perusahaan tiap tahunnya seperti berikut :

Tabel 2 Pasiva PT XYZ 2013-2017 (dalam milliar)

\begin{tabular}{lrrrrr}
\hline \multicolumn{1}{c}{ Pasiva } & $\mathbf{2 0 1 3}$ & $\mathbf{2 0 1 4}$ & $\mathbf{2 0 1 5}$ & $\mathbf{2 0 1 6}$ & $\mathbf{2 0 1 7}$ \\
\hline Kewajiban & & & & & \\
Kewajiban Lancar & 3,462 & 4,372 & 20,755 & 56,687 & 221,992 \\
Kewajiban Jangka Panjang & 16,439 & 21,786 & 37,198 & 124,285 & 502,488 \\
Total Utang & $\mathbf{1 9 , 9 0 0}$ & $\mathbf{2 6 , 1 5 9}$ & $\mathbf{5 7 , 9 5 3}$ & $\mathbf{1 8 0 , 9 7 2}$ & $\mathbf{7 2 4 , 4 8 0}$ \\
Modal & & & & \\
Modal saham & 10,125 & 10,125 & 20,125 & 30,125 & 55,125 \\
Saldo laba & 2,271 & 4,540 & 7,263 & 10,650 & 11,214 \\
Jumlah Modal & $\mathbf{1 2 , 3 9 6}$ & $\mathbf{1 4 , 6 6 5}$ & $\mathbf{2 7 , 3 8 8}$ & $\mathbf{4 0 , 7 7 5}$ & $\mathbf{6 6 , 3 4 0}$ \\
\cline { 2 - 7 } Jumlah Kewajiban dan Modal & $\mathbf{3 2 , 2 9 7}$ & $\mathbf{4 0 , 8 2 4}$ & $\mathbf{8 5 , 3 4 0}$ & $\mathbf{2 2 1 , 7 4 7}$ & $\mathbf{7 9 0 , 8 1 9}$ \\
\hline
\end{tabular}


Dari tabel 2 diatas diketahui bahwa terdapat peningkatan jumlah utang dan ekuitas perusahaan sejak tahun 2013. Diketahui bahwa PT XYZ sejak tahun 2013 hingga 2017 pertumbuhan rata-rata utang jangka pendeknya tumbuh sekitar 216 persen tiap tahun, sementara utang jangka panjangnya tumbuh 160 persen tiap tahunnya. Sementara untuk modal saham dan laba ditahan masing-masing tumbuh secara rata-rata tidak lebih dari 55 persen tiap tahunnya. Hal ini menunjukan bahwa tiap tahunnya PT XYZ membutuhkan pendanaan untuk mengatur struktur modal perusahaannya dalam rangka aktifitas investasi dan operasionalnnya.

Kebijakan pendanaan operasional dan investasi merupakan hal penting yang dapat mempengaruhi return perusahaan. Nilai terbaik didapatkan melalui kombinasi dengan memperhitungkan cost dari tiap instrument pendanaan. Ketidaktepatan kombinasi dapat menyebabkan laba perusahaan menurun, biaya meningkat atau membawa perusahaan kearah kebangkrutan (Brigham, 2000). Dalam aktifitas operasionalnya PT XYZ terus memiliki trend yang positif dari sisi pendapatannya terlihat pada tabel 3 .

Tabel 3 Cashflow PT XYZ 2014-2017 (dalam milliar)

\begin{tabular}{lrrrr}
\hline \multicolumn{1}{c}{ Uraian } & $\mathbf{2 0 1 4}$ & \multicolumn{1}{c}{$\mathbf{2 0 1 5}$} & \multicolumn{1}{c}{$\mathbf{2 0 1 6}$} & \multicolumn{1}{c}{$\mathbf{2 0 1 7}$} \\
\hline Pendapatan usaha bersih & 14.035 & 26.004 & 27.351 & 63.397 \\
Beban pendapatan & 3.753 & 10.592 & 20.587 & 46.788 \\
Laba bruto & 10.282 & 15.412 & 6.764 & 16.609 \\
EBIT & 332 & 4.072 & 2.571 & 2.969 \\
EAT & 2.266 & 2.721 & 3.379 & 564 \\
\hline
\end{tabular}

Sumber : PT XYZ (2017)

Dari tabel 3 mengindikasikan bahwa terdapat peningkatan pendapatan usaha (net sales) tiap tahunnya. Namun pada tahun 2017 nilai earning after tax (EAT) justru menurun drastis. Hal ini diduga dari besar disebabkan dari aktifitas investasi yang dilakukan oleh PT XYZ. Disisi lain mengindikasikan adanya ketidaktepatan penyusunan struktur modal PT XYZ, sehingga harapan untuk meningkatkan value of firm justru terbalik. Selain itu keputusan dalam investasi merupakan aktifitas jangka panjang yang perlu didukung keberlanjutan dari strategi tersebut.Pada posisi yang sama dimana PT XYZ sedang melakukan melakukan aktifitas investasi secara agresif mengalami permasalah yaitu meningkatnya umur piutang perusahaan serta umur utang perusahaan. Padahal saat ini produk bisnisnya \pm 90 persen diserap oleh perusahaan holdingnya.

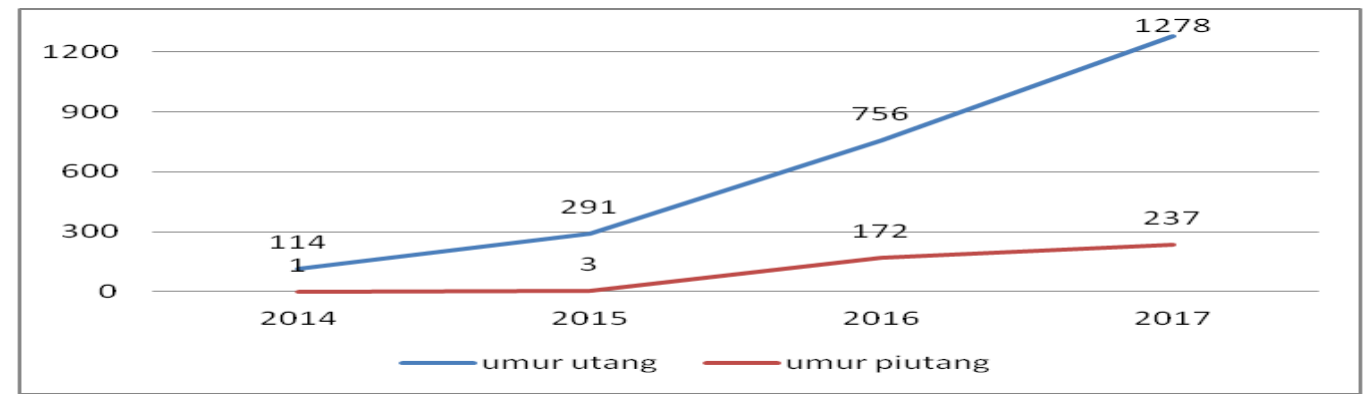

Gambar 2 Trend Umur Utang dan Umur Piutang PT XYZ

Sejak tahun 2014 hingga 2017 umur utang PT XYZ terus bertambah, hal ini menandakan bahwa perusahaan semakin kesulitan untuk memenuhi pembayaran kewajibanya. Diwaktu yang sama PT XYZ juga mengalami permasalahan yaitu tidak lancarnya pembayaran gedung yang disewa khususnya dari holding. Apabila hal ini terus berlanjut dan meningkat sangat dimungkinkan perusahaan mengalami permasalahan keuangan bahkan kebangkrutan. Diperlukan pengelolaan struktur modal yang baik untuk mengatasi permasalah tersebut. Berdasarkan uraian di atas, maka dapat dirumuskan masalah penelitian sebagai berikut:

1. Bagaimana gambaran struktur modal perusahaan saat ini ?

2. Bagaiamana struktur modal optimal pada perusahaan ?

3. Bagaimana pengaruh struktur modal terhadap strategi pembiayaan perusahaaan ? 


\section{KAJIAN PUSTAKA}

Manajemen keuangan merupakan aktifitas kegiatan organisasi dalam merencanakan, menganggarkan, memeriksa, mengelola, mencari serta menyimpan dana yang dimiliki (Fahmi 2011). Struktur modal merupakan perimbangan jumlah utang jangka pendek, utang jangka panjang, saham preferen dan saham biasa (Sartono 2010). Laporan keuangan merupakan hasil akhir dari proses akutansi dari sebuah perusahaan, disusun berdasarkan beberapa account penting yang dapat mengambarkan kondisi perusahaan (Kasmir 2012). Harahap (2007) menjelaskan mengenai rasio keuangan merupakan angka-angka yang diperoleh dari hasil perbandingan dari satu pos laporan keuangan dengan pos yang lainnya yang mempunyai hubungan relevan dan signifikan. Rahma et al (2014) menjelaskan bahwa pada kasus ini pengunaan modal sendiri dianggap lebih baik dari pada meningkatkan penadanaan dari utang hal ini dilakukan untuk mengurangi risiko financial serta meningkatkan value of firm. Mardayaningsih (2012) menjelaskan bahwa pengunaan utang dapat meningkatkan nilai perusahaan disisi lain hal ini juga meningkatkan risiko perusahaan. Naibaho (2012) menjelaskan utang perusahaan dapat memberikan pengaruh positif pada nilai perusahaan namun manajemen perlu memperhatikan kondisi financial distress agar aktifitas rancangan struktur modal tersebut tidak menimbulkan risiko default bagi perusahaan. Amanah (2006) menjelaskan bahwa penambahan utang memberikan pengaruh signifikan terhadap peningkatan nilai perusahaan, namun hal tersebut tidak signifikan dalam peningkatan return perusahaan. Vuorikari (2012) menjelaskan bahwa perusahaan akan terus mencari komposisi terbaik yang dapat dilakukan dalam rangka meningkatkan nilai perusahaan, disisi lain hal berpegaruh terhadap presepektif masa depan perusahaan dalam hal memilih pendanaan terbaik dari modal dan atau utang. menjelaskan bahwa optimalisasi modal kerja merupakan hal penting yang dapat berguna pada peningkatan cash perusahaan. Hal ini diketahui bahwa cash yang tersedia dan mampu digunakan untuk memenuhi kewajiban menandakan perusahaan tersebut aman dari hal-hal yang membahayakan.

\section{METODE PENELITIAN}

Penelitian ini dilakukan pada bulan Maret hingga Juni 2018 dengan objek PT XYZ yang berkantor di Menara Taspen Sudirman Jakarta. Penelitian ini bersifat studi kasus dengan objek kondisi keuangan PT XYZ. Analisis berfokus pada rumusan struktur modal terbaik untuk perusahaan serta mengetahui kondisi financial distress PT XYZ.Data yang digunakan dalam penelitian ini bersifat data sekunder. Data didapatkan mengacu pada informasi yang telah dikumpulkan dari sumber yang telah ada. Data sekunder yang digunakan dalam penelitian ini adalah annual report PT XYZ, jurnal, penelitian terdahulu serta referensi yang dapat dipertangung jawabkan lainnya.

Metode analisa yang digunakan dalam menjawab permasalahan dalam penelitian ini seperti berikut: 1)Analisis pada rasio keuangan, dilakukan identifikasi dan analisis terhadap laporan keuangan perusahaan dimana selanjutnya dilakukan perhitungan untuk mendapatkan beberapa rasiorasio penting keuangan, digunakan untuk memberikan gambaran kinerja keuangan dari waktu ke waktu. 2)Analisis kebutuhan modal kerja, analisis kebutuhan modal kerja menggunakan pendekatan agresif sesuai dengan strategi perusahaan yang sedang berjalan yaitu strategi pengembangan yang agresif melalui gedung dalam jumlah besar setiap tahun. 3) Analisis Struktur Modal Optimal, analisis struktur modal optimal ditentukan dengan teknik yang melewati beberapa proses penting. Menghitung cost of capital serta nilai perusahaan dari masa penelitian, dengan menggunakan pendekatan Modligliani Miller dan TraditionalApproach.Membuat penetapan target struktur modal berdasarkan asumsi perpetual cash flow serta judgemental. 4) Analisis kebangkrutan perusahaan, Analisis kebangkrutan perusahaan dilakukan dengan cara menganalisis kondisi berdasarkan empat kategori kesulitan keuangan. Pranowo etal (2010) menjelaskan bahwa terdapat empat pengelompokan proses financial distress. 


\section{HASIL DAN PEMBAHASAN}

\section{Analisis Kinerja Keuangan}

Kinerja keuangan yang didapat dari kegiatan operasi perusahaan disajikan dalam bentuk angka-angka keuangan. Hasil kegiatan operasional perusahaan dinilai berdasarkan tiap tahun, trend ditiap tahunnya (horizontal) dan perbandingan dengan tiap accountnya (vertikal). Hasil penilaiain tersebut dapat digunakan sebgai perbandingan dan rekomendasi untuk operasional perusahaan kedepannya.

Analisis rasio keuangan perusahaan digunakan sebagai dasar untuk mengetahui informasi umum terkait kinerja dari empat kategori penilaian yaitu rasio likuiditas, laverage, profitabilitas, dan aktifitas (Harahap 2004). Umumnya perhitungan rasio-rasio data keuangan dilakukan untuk menilai kinerja suatu perusahaan dimasa lalu, masa sekarang, dan perkiraan atau berbagai kemungkinan yang terjadi pada masa yang akan datang. Adapun rasio keuangan perusahaan sejak tahun 2013-2017 disajikan pada Tabel 4.

Tabel 4 Analisa Rasio Keuangan PT XYZ

\begin{tabular}{|c|c|c|c|c|c|}
\hline URAIAN & 2013 & 2014 & 2015 & 2016 & 2017 \\
\hline \multicolumn{6}{|l|}{ RASIO PROFITABILITAS } \\
\hline GPM & 0,49 & 0,73 & 0,59 & 0,25 & 0,26 \\
\hline OPM & 0,26 & 0,40 & 0,28 & 0,34 & 0,54 \\
\hline NPM & 0,12 & 0,16 & 0,10 & 0,06 & 0,01 \\
\hline \multicolumn{6}{|l|}{ RASIO AKTIVITAS } \\
\hline ROA & 0,07 & 0,08 & 0,05 & 0,01 & 0,00 \\
\hline ROE & 0,14 & 0,15 & 0,10 & 0,04 & 0,01 \\
\hline TAT & 0,44 & 0,34 & 0,30 & 0,12 & 0,08 \\
\hline ART & 56,40 & 162,90 & 34,57 & 2,12 & 1,54 \\
\hline APT & 0,86 & 0,66 & 0,72 & 0,23 & 0,13 \\
\hline WCT & 4,46 & 4,49 & 4,96 & 0,53 & 1,60 \\
\hline \multicolumn{6}{|l|}{ RASIO SOLVABILITAS } \\
\hline DAR & 0,62 & 0,64 & 0,68 & 0,82 & 0,92 \\
\hline DER & 1,61 & 1,78 & 2,12 & 4,44 & 10,92 \\
\hline \multicolumn{6}{|l|}{ RASIO LIKUIDITAS } \\
\hline $\mathrm{CR}$ & 1,92 & 1,71 & 1,25 & 1,91 & 1,18 \\
\hline $\mathrm{QR}$ & 1,92 & 0,57 & 1,09 & 1,89 & 1,17 \\
\hline CAR & 1,43 & 0,25 & 0,47 & 0,18 & 0,14 \\
\hline
\end{tabular}

Analisis laverage digunakan untuk mengidentifikasi perbandingan dana yang disediakan oleh pemiliknya dengan dana pinjaman dari kreditur, selain itu rasio ini mengukur seberapa jauh aktiva perusahaan yang dibiayai dengan utang dari para pembeli pinjaman sesuai dengan prinsip akutansi. Analisis laverage juga berfungsi sebagai mengetahui kemampuan perusahaan dalam membayar seluruh kewajiban jangka pedek dan jangka panjang. Sejak tahun 2013 diketahui bahwa nilai DAR perusahaan telah diatas 50 persen yang artinya hampir seluruh aset yang dimiliki perusahaan dibiayai oleh kewajiban. diwaktu yang sama nilai DER perusahaan masih berada pada 1,61 yang menandakan bahwa nilai tersebut masih aman dari batasan yang telah ditetapkan oleh pemerintah(Peraturan Menteri Keuangan nomor 169/PMK.010/2015). Peningkatan nilai rasio laverage signifikan pada tahun 2016 dan 2017. Pada tahun 2016 nilai rasio DER mencapai 4,44 yang telah berada diatas standard yang ditetapkan(Peraturan Menteri Keuangan nomor 169/PMK.010/2015). . Terjadi peningkatan ditahun 2017 menjadi 10,92. Pada dasarnya sejak kondisi 2016 perusahaan dapat dipastikan akan mengalami kesulitas untuk menambah pinjaman jangka panjangnya melalui pihak perbankan. Perusahaan masih bisa mendapatkan pinjaman dalam bentuk pinjaman berelasi dari anak perusahaan holding lainnya dan tetap diwajibkan membayarkan bunga atas pinjaman tersebut.

Analisis rasio aktivitas merupakan rasio yang digunakan untuk mengukur efektifitas dan efisien perusahaan dalam memanfaatkan aset dalam menghasilkan pendapatan. Rasio ini juga digunakan untuk mengukur efektifitas dan efisien perusahaan dalam memanfaatkan aset dalam menghasilkan pendapatan. Rasio ini juga digunakan untuk mengukur kemampuan bisnis dalam mengubah berbagai jenis aset menjadi uang tunai. Berdasarkan perhitungan dan kasus pada PT XYZ. diketahui bahwa nilai rasio TATO mengalami penurunan signifikan yang disebabkan telah tersewanya seluruh bangunan yang dimiliki oleh perusahaan. Temuan ini disebabkan asset yang dimiliki tidak mampu dimanfaatkan dari waktu ke waktu.

Analisis profitabilitas digunakan untuk mengetahui kemampuan perusahaan untuk mendapatkan laba dari earning atas aktivitas perusahaan. Rasio profitabilitas diperlukan untuk menilai jumlah laba investasi yang diperoleh perusahaan atas investasi yang dilakukannya. Efektifitas dan efisiensi manajemen dapat terlihat pada rasio profitabilitas. Kebijakan agresif perusahaan untuk terus menambah jumlah aset tetap. yang diharapkan dapat meningkatkan pendapatan perusahaan justru memberikan dampak sebaliknya, hal tersebut dapat terlihat dari rasio profitabilitas yang mengalami penurunan cukup signifikan disetiap tahunnya, kondisi ini terjadi akibat adanya peningkatan beban 
perusahaan yang tidak mampu dimanfaatkan untuk mendapatkan pendapatan. Adapun komponen pendapatan PT XYZ yaitu sewa bangunan (kantor), jasa pengadaan kantor, sewa kendaraan (motor dan mobil), sewa genset dan sewa lemari fire proff. Menurunnya profit PT XYZ disebabkan didominasi oleh aktivitas bisnis sewa. Untuk ditahun sebelumnnya PT XYZ masih mendapatkan tambahan keuantungan dari penjualan properti serta pendapatan lainnya.

Analisis likuiditas berguna sebagai informasi kemampuan perusahan dalam mengelola kewajiban dana untuk membayar utang jangka pendeknya. Jika perusahaan mampu memenuhi kewajibannya maka perusahaan dinilai likuid, sementara jika tidak dapat memenuhi kewajibannya maka perusahaan dinilai ilikuid. Sejak tahun 2013 hingga 2017 kemampuan membayar perusahaan mengalami penurunan yang signifikan pada seluruh rasio. Kasus yang terjadi pada PT XYZ disebabkan, yaitu: 1) Meningkatnya pendapatan diterima dimuka, sejak tahun 2014-2015 terjadi peningkatan pendapatan dibayar dimuka sebesar 5 kali, pada tahun 2015-2016 terjadi peningkatan lebih dari 2,5 kali lipat dan pada tahun 2016-2017 terjadi peningkatan lebih dari 4 kali lipat. 2) Pada pos lainnya yang masuk dalam kategori utang jangka pendek diketahui tidak mengalami peningkatan yang signifikan. Pada utang berelasi serta utang usaha ditahun 2017 tidak ditemukan nilai.

\section{Perhitungan Struktur Modal Optimal Perusahaan}

Perhitungan kondisi perusahaan ditiap tahunnya dapat dijadikan gambaran penting terkait seberapa besar penyimpangan yang terjadi dengan perhitungan optimalnnya. Hal ini juga dapat dijadikan gambaran dalam rangka menyusun proyeksi ditahun depan. Adapun besaran didapat seperti pada Tabel 5.

Tabel 5 Perbandingan Simulasi Debt, Firm Value dan WACC dengan Kondisi Realita

\begin{tabular}{|c|c|c|c|c|c|c|}
\hline \multirow{2}{*}{ Tahun } & \multicolumn{3}{|c|}{ Simulasi } & \multicolumn{3}{|c|}{ Realita } \\
\hline & Debt & WACC & $\begin{array}{l}\text { Firm } \\
\text { Value }\end{array}$ & Debt & WACC & Firm Value \\
\hline 2013 & $90 \%$ & $10,47 \%$ & 350.435 & $6162 \%$ & $926 \%$ & 172,140 \\
\hline 2014 & $15 \%$ & $9,86 \%$ & 517,861 & $64.08 \%$ & $10.34 \%$ & 29,922 \\
\hline 2015 & $95 \%$ & $9,58 \%$ & 613,069 & $67.91 \%$ & $9.16 \%$ & 342,406 \\
\hline 2016 & $95 \%$ & $13,33 \%$ & 599,546 & $81.61 \%$ & $9.80 \%$ & 224,262 \\
\hline 2017 & $80 \%$ & $1,58 \%$ & 769,644 & $91.61 \%$ & $11.83 \%$ & 293,575 \\
\hline
\end{tabular}

Berdasarkan Tabel 5 didapat informasi bahwa komposisi debt perhitungan simulasi dan realita ditemukan perbedaan nyata. Pada tahun 2013 diketahui bahwa 61,62 persen pendanaan perusahaan dibiayai oleh utang, sementara pada simulasi memberikan gambaran bahwa perusahaan dapat meningkatkan komposisi utangnya dalam rangka implementasi strategi perusahaan. Dampak dari peningkatan utang ditahun 2013 dapat meningkatkan firm value menjadi lebih dari dua kali lipat nilai semula, disisi lain perusahaan harus menanggung sedikit tambahan biaya rata-rata tertimbang akibat hal tersebut.

Pada tahun 2015 dan 2016 diketahui bahwa bahwa perusahaan juga dapat meningkatkan komposisi utang untuk membiayai strategi perusahaan. Pada tahun 2015 dan 2016 dapat meningkatkan proporsi utang sampai dengan 95 persen. Peningkatan utang berdampak pada peningkatan nilai firm value perusahaan menjadi jauh lebih besar dari pada kondisi realita namun hal ini berdampak pada meningkatnya biaya tertimbang yang cukup signifikan. Pada tahun 2017 PT XYZ perlu mempertimbangkan untuk menambah utang, hal ini disebabkan pada perhitungan simulasi menunjukan bahwa perusahaan perlu menurunkan komposisi utangnya sampai menjadi 80 persen. Kondisi ini dapat memberikan keuntungan perusahaan yaitu rendahnya biaya tertimbang serta meningkatkan firm value secara signifikan. Pada Tabel terdapat informasi yang anomali yang terjadi ditahun 2014. Kondisi tersebut disebabkan EBIT perusahaan turun secara drastis sehingga tidak mampu memberikan kondisi perhitungan yang optimal dengan menggunakan debt yang terjadi pada tahun 2014. Perhitungan pada tahun 2014 memberikan rekomendasi kepada PT XYZ untuk dapat memilih komposisi debt yang masih mampu memberikan EAT yang positif. 


\section{Analisis Modal Kerja}

Analisis kebutuhan modal kerja dalam implementasi strategi agresif merupakan hal yang penting. Analisis ini berguna untuk mengetahui elemen yang sangat penting dalam perusahaan yang dapat diperhatikan pihak manajemen perusahaan dalam menjalankan kegiatan usahanya. Pada dasarnya dana yang dimiliki PT XYZ seluruhnya akan digunakan untuk menghasilkan laba sesuai dengan usaha pokok perusahaan.Proses perhitungan kebutuhan modal kerja menggunakan data-data realisasi laba rugi dan neraca perusahaan pada tahun 2017 serta rencana kerja perusahaan tahun 2018. Perhitungan kebutuhan modal kerja tidak memperhitungkan pembayaran kepada pihak ketiga terkait dengan kredit yang telah berjalan.

Tabel 6 Analisis Modal Kerja Perusahaan

\begin{tabular}{|c|c|c|c|c|c|c|c|c|}
\hline \multirow[b]{2}{*}{ Tahun } & \multicolumn{5}{|c|}{ Umur Perputaran Modal Kerja } & \multirow{2}{*}{$\begin{array}{c}\text { Perputaran } \\
\text { modal kerja } \\
\quad \text { (Hari) }\end{array}$} & \multirow{2}{*}{$\begin{array}{l}\text { Kebutuhan } \\
\text { Modal Kerja } \\
\text { (Rp Juta) }\end{array}$} & \multirow{2}{*}{$\begin{array}{c}\text { Modal } \\
\text { Kerja } \\
\text { Tersedia } \\
\text { (Rp Juta) } \\
\end{array}$} \\
\hline & Kas \& Bank & Piutang & Persediaan & Utang & Total & & & \\
\hline 2014 & 78,7 & 0,7 & 242,9 & 101,8 & 220,5 & 1,7 & 8.477 & 6.124 \\
\hline 2015 & 76,6 & 5,4 & 141,7 & 38,6 & 185,1 & 2 & 13.186 & 13.790 \\
\hline 2016 & 131,8 & 91,1 & 38,8 & 46,9 & 214,9 & 1,7 & 16.101 & 24.008 \\
\hline 2017 & 117,4 & 155,7 & 9,0 & 87,5 & 194,6 & 1,9 & 33.800 & 73.152 \\
\hline
\end{tabular}

Pada Tabel 6 diketahui bahwa disetiap tahunnya diketahui bahwa perputaran utang ditiap tahunnya berfluktuatif. Diketahui pada tahun 2014 mengalami permasalahan perputaran utang yang telah mencapai 101,8 hari. Kondisi ini telah telah melebihi batasan yang ditentukan dalam perusahaan yaitu 90 hari. PT XYZ pada tahun berikutnya 2015 hingga 2017 berhasil memperbaiki hari perputaran utangnya menjadi dibawah 90 hari. Meningkatnya jumlah hari pada perputaran utang dapat memberikan dampak buruk pada perusahaan, dimana menurunnya kepercayaan dari para mitra terhadap PT XYZ serta bertambahnya beban bunga jika hal tersebut memiliki cost of debt.

Perputaran modal kerja pada sisi aktifa diketahui memiliki nilai yang cenderung naik pada akun kas \& bank dan piutang. Pada dasarnya kondisi ini menunjukan bahwa kinerja perusahaan menurun. Waktu perputaran kas \& bank yang meningkat menginndikasikan bahwa PT XYZ saat ini sedang mengalami kebutuhan modal namun hal tersebut tidak dapat dipenuhi dalam waktu cepat. Kondisi piutang yang meningkat mengindikasikan bahwa perusahaan tidak mampu mengelola secara efektif untuk menarik kewajiban dari perusahaan lainnya. Disisi lain diketahui bahwa terjadi penurunan persediaan yang signifikan, hal ini disebabkan adanya produk perumahan yang laku terjual.

Pada dasarnya kondisi kebutuhan modal kerja dengan modal kerja tersedia dalam kondisi existing telah terpenuhi dengan baik, namun pada tahun 2014 mengalami permasalahan kebutuhan modal kerja. Hal ini disebabkan kebutuhan modal kerja PT XYZ jauh melebihi ketersediaan modal kerja perusahaan. Kondisi ini memerlukan suatu perhatian khusus dengan cara melakukan rasionalisasi umur utang perusahaan sehingga didapatkan kondisi yang lebih baik dari pada awalnya. Strategi agresif yang dilakukan oleh perusahaan menyebabkan adanya peningkatan dalam jumlah modal kerja perusahaan. Harapannya bahwa peningkatan modal kerja dapat mendorong profitabilitas perusahaan, namun pada kenyataannya justru mengalami penurunan ditiap waktunya

\section{Implikasi Manajerial}

Berdasarkan hasil analisa di atas, terdapat beberapa hal penting yang perlu dilakukan manajemen PT XYZ untuk dalam rangka meningkatkan kinerja keuangan yang terkait dengan implementasi strategi agresifnya adapun yaitu :

a. Manajemen perlu melakukan review terhadap aktifitas penambahan jumlah gedung baru untuk disewakan. Hal ini disebabkan penambahan gedung-gedung baru mampu meningkatkan jumlah cash perusahaan menjadi begitu cepat akibat adanya pendapat yang diterima dimuka. PT XYZ perlu melakukan review terhadap usaha-usaha lain baik yang telah dilakukan namun belum efektif dalam menghasilkan profit untuk perusahaan serta usaha yang belum dilakukan namun masih dalam core business perusahaan. 
b. Aktifitas penghematan pada beban pendapatan serta beban operasional perusahaan. Hal ini dirasa penting karena dengan ditemukan cara menekan beban sampai batas terbaik dapat memberikan perbaikan pada laporan kinerja serta operasional keuangan perusahaan.

c. Manajemen PT XYZ telah mengetahui aktifitas operasional perusahaan cenderung memiliki trend yang menurun. Kondisi ini berbahaya jika dibiarkan terus menerus. PT XYZ dapat melakukan perbaikan pada percepatan pelunanan utang agar mendapatkan potongan atau diskon transaksi yang dilakukan. Perusahaan juga dapat melakukan pencairan piutang yang lebih cepat yang akan berdampak pada meningkatnya perputaran modal kerja perusahaan.

d. Manajemen telah mengetahui bahwa penggunaan utang merupakan cara yang dapat dilakukan untuk melakukan ekspansi bisnis. Disisi lain hal ini telah berdampak buruk pada perusahaan, dimana terjadi peningkatan nilai cost of capital dari PT XYZ. Perusahaan perlu melakukan update secara berkala untuk mengetahui komposisi struktur modal terbaik. Pada kasus perusahaan saat ini perlu memperhatikan dana-dana yang berasal dari ekuitas yang bertujuan dapat mengurangi risiko kegagalan bayar dari perusahaan, hal ini dilakukan disebabkan telah tingginya biaya modal yang memilikibunga tambahan yang bersifat wajib.

e. Manajemen perlu mempertimbangkan opsi untuk merger dengan anak Perusahaan lainnya yang memiliki kinerja bisnis lebih baik sehingga dapat menjadi Perusahaan yang lebih sehat dan juga berpengaruh terhadap kinerja keuangan Konsolidasi.

\section{KESIMPULAN}

Terdapat beberapa kesimpulan dalam penelitian ini berdasarkan rumusan masalah yang dilakukan, adapun seperti berikut :

1. Kinerja keuangan PT XYZ selama periode penelitian (strategi agresif) mengalami kecenderungann negatif hampir diseluruh rasio keuangan. Hal ini tergambarkan pada rasio solvabilitas yang meningkat tajam ditiap tahunnya, yang menandakan perusahaan terus meningkatkan komposisi utang untuk memenuhi investasinya. Pada rasio aktifitas diketahui mengalami penurunan yang menandakan bahwa dengan penambahan aset perusahaan justru mengalami penurunan pada kinerjanya. Rasio profitabilitas dari PT XYZ mengalami penurunan signifikan yang disebabkan meningkatnya beban perusahaan. Pada rasio likuiditas juga mengalami penurunan signifikan dimana sampai perusahaan tidak mampu memenuhi kewajiban lancarnya dengan menggunakan aktifa lancarnya.

2. Kondisi struktur modal dari PT XYZ diketahui lebih baik menggunakan pendekatan tradisional karena mampu memberikan nilai WACC yang lebih kecil dari pada menggunakan pendekatan modligliani miller. Diketahui terjadi perbedaan komposisi utang optimal dari perhitungan simulasi dengan perhitungan realita. Pada tahun 2013, 2015 dan 2016 perusahaan direkomendasikan untuk meningkatkan jumlah pinjamannya, sementara pada tahun 2014 dan 2017 perusahaan direkomendasikan untuk mengurangi jumlah pinjamannya.

3. PT XYZ dalam mengelola modal kerjanya dapat memenuhi kebutuhan hampir disetiap tahun kecuali pada tahun 2014. Ditemukan bahwa diperlukan perbaikan pada perputaran umur piutang dan umur utang, untuk memperbaiki kinerja perusahaan.

Saran

Berdasarkan hasil penelitian beberapa saran yang dapat menjadi pertimbangan adalah :

1. Statergis teoritis terkait dengan melakukan pencarian factor yang mempengaruhi struktur keuangan perusahaan dengan pendekatan regresi

2. Saran praktis pada penelitian ini terkait dengan manajemen perlu melakukan review pada implementasi strategi dari holding untuk terus menambah jumlah bangunan yang disewakan kepada perusahaan lain. Dalam waktu dekat perusahaan perlu melakukan perbaikan dalam pembiayaan perusahaan dalam rangka untuk menjaga eksistensi perusahaan. Hal ini dapat dilakukan dengan aktivitas refinancing serta menambah jumlah ekuitas perusahaan 


\section{REFERENSI}

Amanah L. 2006. Analisis struktur modal dan nilai perusahaan yang diukur dengan tobins'q. Ekuitas. $11(2): 255-268$

Brigham EF. 2000. Fundamaental of Financial Management. New York (US) : Dryeden Press

Fahmi I. 2011. Analisis Laporan Keuangan. Bandung (ID) : Alfabeta

Harahap SS. 2004. Akuntansi aktiva tetap. Jakarta (ID) : Raja Grafindo

Harahap SS. 2007. Analisis kritis atas laporan keuangan. Jakarta (ID) : Raja Grafindo

Ikatan Akuntan Indonesia. 2009. Standar Akuntansi Keuangan; PSAK No.2. Salemba Empat. Jakarta

Kasmir. 2012. Analisis laporan keuangan. Jakarta (ID) : Raja grafindo persada

Mardayaningsih W. 2012. Analisis optimasi struktur modal pada pt. Pusri (persero). Jurnal keuangan. $1(2): 21-30$

Naibaho O. 2012. Analisis struktur modal optimal pt.x [Tesis]. Depok (ID) : Universitas Indonesia

Peraturan Menteri Keuangan nomor 169/PMK.010/2015

Rahma SA, Darminto, Topowijono. 2014. Analisis penetapan struktur modal yang optimal guna meningkatkan nilai perusahaan (studi pada pt. Seemount garden sejahtera, jiwan, kabupaten madiun periode 2011-2013). Jurnal administrasi bisnis. 13(1) : 1-10

Sartono. 2010. Manajemen keuangan teori dan aplikasi. Yogjakarta (ID): BPFE

Vuorikari M. 2012. Optimizing Working Capital Management from Processes Perspective [Tesis]. Lappeenranta (FN) : Salmaa University of applied sciences 